\title{
Regionális klaszterek és agglomerációs előnyök: feldolgozóipar a magyar városrégiókban
}

\author{
Regional clusters and agglomeration advantages: \\ manufacturing in Hungarian urban areas
}

\author{
VAS ZSÓFIA, LENGYEL IMRE, SZAKÁLNÉ KANÓ IZABELLA
}

VAS Zsófia: egyetemi adjunktus, Szegedi Tudományegyetem, Gazdaságtudományi Kar, Közgazdaságtani és Gazdaságfejlesztési Intézet, Szeged; vas.zsofia@eco.u-szeged.hu LENGYEL Imre: intézetvezető egyetemi tanár, Szegedi Tudományegyetem, Gazdaságtudományi Kar, Közgazdaságtani és Gazdaságfejlesztési Intézet, Szeged; ilengyel@eco.u-szeged.hu SZAKÁLNÉ KANÓ Izabella: egyetemi adjunktus, Szegedi Tudományegyetem, Gazdaságtudományi Kar, Közgazdaságtani és Gazdaságfejlesztési Intézet, Szeged; kano.izabella@eco.u-szeged.hu

KULCSSZAVAK: regionális klaszter, agglomerációs előnyök, városrégiók, specializáció

ABSZTRAKT: A régiók és várostérségek gazdasági növekedésének és fejlődésének egyik forrása gazdaságuk specializációja. Az a térség, amely képes az ott működő bázis (traded) jellegű húzóágazatok megerősítésére, komoly előnyhöz juthat a területi versenyben. A húzóágazatok azonosításának egyik hasznos eszköze a klaszterek feltérképezése, a régióban meghatározó súllyal bíró, növekedésre képes, innovációs együttműködéseken alapuló gazdasági szerveződések feltárása. Az Európai Unió 2014-2020 közötti regionális politikája is kiemelten kezeli a régiók intelligens szakosodásának elősegítését, amelyben a klaszterek fontos szerepet töltenek be.

A dinamikus növekedésre képes bázisszektorok jelentős része Magyarországon a feldolgozóiparból áll, amelyhez a foglalkoztatottak, az export és a technológiai újítások jelentős része kötődik. Jelen tanulmány célja a feldolgozóipari alágak térbeli eloszlásának és klaszteresedéshez szükséges kritikus tömegének felmérése Magyarország nagyvárosi településegyütteseiben, városrégióiban. A klaszterfeltérképezés eredményei felhasználhatók a városrégiók újraiparosodáson alapuló intelligens szakosodási stratégiájának kidolgozásához is.

Zsófia VAS: assistant professor, Institute of Economics and Economic Development, Faculty of Economics and Business Administration, University of Szeged; vas.zsofia@eco.u-szeged.hu Imre LENGYEL: professor, head of institute, Institute of Economics and Economic Development, Faculty of Economics and Business Administration, University of Szeged; ilengyel@eco.u-szeged.hu Izabella SZAKÁLNÉ KANÓ: assistant professor, Institute of Economics and Economic Development, Faculty of Economics and Business Administration, University of Szeged; kano.izabella@eco.u-szeged.hu

KEYWORDS: regional clusters, agglomeration advantages, urban areas, specialization

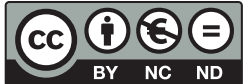


ABSTRACT: Specialisation of regions and urban areas is one of the main sources of economic growth and development. The region which is able to strengthen its key traded sectors can gain significant advantages in regional competition. An efficient approach to identify a region's key sectors is cluster mapping which is designed to reveal geographical concentration of growing, dominant and innovative economic activities.

For the years between 2014 and 2020, it has been declared a high priority of EU regional policy making to promote smart specialisation and re-industrialisation - in which regional clusters play an important role. The changes in the global economy as well as economic shocks have made it crucial to identify all potential economic activities in regions that reach a critical mass, have higher innovation capabilities and contribute to the development of regional competitive advantages. Among all traded economic activities, manufacturing has become vital in Hungary. It promotes technological innovation, productivity and trade, produces for export, generates economic growth and employment, and has an increasing demand for services.

Given that place-based policies put a particular emphasis on the spatiality of economic activities, it is important to determine what characterises the spatial distribution of manufacturing in the urban areas of Hungary, and which sectors have reached a critical mass for clustering.

Therefore the present study analyses the spatial distribution and the critical mass of manufacturing subsections in Hungarian urban areas. It shows which manufacturing subsections in Hungary could reach and maintain its critical mass between the time of Hungary's accession to the EU in 2004 and the time of the global economic crisis. We examine the spatial distribution on the level of urban areas because they reflect residential, business and labour relations. The study follows the slightly modified methodology of cluster mapping developed by the European Cluster Observatory, which identifies potential clusters based on three criteria: size, specialisation and focus. We use data on employees, and we compare the results of two years, 2005 and 2010. As we expected, we can demonstrate which sectors in manufacturing are worth specialising in by urban areas and whose support contributes to the further development of regions. The main conclusion is that Hungarian urban areas have different developmental trajectories, and we might witness re-industrialisation processes only in a few, less developed regions in Hungary.

\section{Bevezetés}

A régiók gazdasági növekedésével és fejlődésével foglalkozó számos elmélet közül talán a legjelentősebb az endogén növekedés elmélete, amely a tudást, valamint a technológiát térségen belülinek, endogénnek tekinti, és a térségben meglévő helyi adottságok jelentőségét hangsúlyozza (Capello 2007; Romer 1994). Ez az elméleti elgondolás a globalizáció térnyerésével és a tudásalapú gazdaság fejlődésével párhuzamosan jelent meg, amikor nyilvánvalóvá vált, hogy egy térség versenyképességének javulása a térség egyedi jellemzőitől (Capello 2008; Lengyel 2010), valamint a térségben földrajzilag koncentrálódó gazdasági tevékenységektől és e tevékenységek szakképzett munkaerőre, iparági szaktudásra, kutatás-fejlesztési kapacitásokra stb. való specializációjától függ (Krugman 2000).

A térbeli elhelyezkedés jelentőségével, valamint a földrajzi koncentrációból eredő előnyök elemzésével az elméleti közgazdaságtudomány ismert alakjain túl az üzleti tudományok irányzatának képviselői, így Michael Porter is 
foglalkoznak (Lengyel, Rechnitzer 2004). Porter rávilágít arra, hogy a vállalatok versenyképessége a kifinomult működést biztosító belső vállalati tényezőkön túl a különösképpen innovációs tevékenységek ösztönzése szempontjából fontos helyi üzleti környezet kiépültségétől függ (Lengyel 2010; Porter 1998). E szemlélet az Európai Unió 2014-2020 közötti regionális politikájában is megjelenik, amely a helyalapú (place-based), alulról szerveződő, integrált és intelligens szakosodást elősegítő fejlesztési stratégiákat helyezi előtérbe (EC 2013, 2014).

Mind az elméleti irányzatok, mind pedig a nemzetközi gyakorlat rávilágított arra, hogy régiók gazdasági növekedésének egyik forrása a klaszterekben keresendő, amelyek a tartós iparági versenyelőnyök, az innováció és a térbeli koncentráció nyújtotta előnyök együttes megvalósulását biztosítják (Porter 1998, 2000). Az 1990-es évektől a fejlett térségekben jól bevált, sikeres klaszterkoncepciót egy évtizeddel később a kevésbé fejlett régiók gazdaságának fejlesztésében is elkezdték alkalmazni, így többek között Magyarországon. Ezekben a régiókban a klaszterek kialakulási lehetőségei azonban kedvezőtlenebbek. Porter (2004) a rurális térségek, Tödtling és Trippl (2005) a periferikus régiók, Rosenfeld (2002) a kedvezőtlen adottságú régiók, Lagendijk és Lorentzen (2007) az ún. nem magterületek, Lengyel (2010) a neofordista régiók példáján keresztül mutatja be azokat az eltérő intézményi, társadalmi és gazdasági háttérfeltételeket, amelyekkel a potenciális klasztereknek egy kevésbé fejlett régióban szembe kell nézniük. A kedvezőtlenebb adottságoknak betudhatóan ezekben a régiókban a gazdasági tevékenységek kisebb földrajzi koncentrációja figyelhető meg, aminek következtében a pozitív extern hatások kevésbé érvényesülnek, és a gazdasági szereplők közötti tudás terjedésének is kisebb az esélye. Mindezek ellenére a klaszterszerveződések helyi kezdeményezésre itt is létrejöhetnek, az agglomerációs előnyök kihasználásával, a köz- és magánszféra közreműködésével, az egyre nagyobb mértékben rendelkezésre álló pénzügyi források segítségével.

Legyen szó fejlett vagy kevésbé fejlett régióról, a klaszterek kialakulásának elsődleges feltétele a gazdasági szereplők kritikus tömege egy olyan iparágban, üzletágban, amely dinamikus fejlödésre képes. Ilyen gazdasági tevékenységek jellemzően a bázisszektorban (traded sector) találhatók, ahol a vállalkozások a termelésük folyamatos bővítésére és jelentős mértékủ helyi és régión kívüli kereslet kielégítésére képesek. E vállalkozások számos új munkahelyet hoznak létre, általában erős együttmüködési és innovációs hajlandóság jellemzi őket, továbbá a beáramló jövedelem révén a régió gazdasági növekedéséhez járulhatnak hozzá (Lengyel 2010; Lengyel, Rechnitzer 2004).

A bázisszektor jelentős része a feldolgozóiparból áll, főleg a kevésbé fejlett régiókban, így Magyarországon is. A feldolgozóipar a gazdaság egészének müködését befolyásolja, átalakulása a régiókban tovagyűrűző hatásokat eredményez. A feldolgozóiparban bekövetkezett változások hatással vannak a termelékenység, a foglalkoztatottság, a befektetői és a fogyasztói kedv alakulására. A szolgáltatások többsége is valamilyen feldolgozóipari tevékenységhez kapcsolódik, következésképpen a feldolgozóipari tevékenységek és szolgáltatások együt- 
tes jelenléte nagymértékben befolyásolja a régiók gazdaságának növekedését. Többek között e felismerés vezetett az újraiparosodás, újraiparosítás előtérbe kerüléséhez az Európai Unióban (EC 2013).

A hazai szakirodalomban több kutatás foglalkozik a magyar ipar sajátosságaival, annak területi szerkezetével (Barta 2002; Kiss 2010; Lux 2009; Szakálné Kanó 2011). Azonban kevés tapasztalattal rendelkezünk arról, hogy a feldolgozóipari tevékenységek Magyarország csomóponti régióiban (ahol eltérő agglomerációs előnyök jellemzőek) hogyan „viselkednek”. Jelen tanulmány célja a feldolgozóipar Magyarország városrégióiban való súlyának feltérképezése. Feltárjuk, hogy a 13 feldolgozóipari alág térbeli koncentrációjának milyen jellegzetességei figyelhetők meg, valamint felmérjük, hogy a feldolgozóipari alágak elérik-e a klaszteresedéshez szükséges kritikus tömeget a magyarországi csomóponti régiókban. A kutatási kérdés megválaszolásához bemutatjuk a klaszterek jelentőségét és a klaszterek agglomerációs előnyök alapján való tipizálását. Kitérünk a feldolgozóipar magyar gazdaságban betöltött szerepére, majd az European Cluster Observatory módszertanát átvéve, azt némileg módosítva, feltérképezzük a potenciális feldolgozóipari klasztereket. A városi térségek, városi településegyüttesek alkalmazásának előnye, hogy a napi térpályát, a tényleges térbeli lakossági, üzleti, munkaerő-kapcsolatokat jobban tükrözik, mint a közigazgatási egységek (járások vagy megyék). A feldolgozóipari alágak városi településegyüttesekben való kritikus tömegét az alkalmazottak száma alapján vizsgáljuk.

\section{Regionális klaszterek és agglomerációs előnyök típusai}

A regionális klaszter az egymáshoz kölcsönösen kapcsolódó vállalkozások földrajzilag jól körülhatárolható köre (Rosenfeld 2002), olyan szerveződés, amelyben a tudásteremtő, -terjesztő, valamint a tudáskiaknázó szereplők a térben koncentrálódnak (Trippl, Tödtling 2008; Wixted 2009). A klaszter egy adott iparág vállalatainak (beleértve a specializált szállítókat), tudásteremtő szervezeteknek (egyetemek, kutatóintézetek stb.), hídképző intézményeknek (brókerek, tanácsadók) és a szofisztikált fogyasztóknak szoros, földrajzilag körülhatárolható kapcsolatrendszere (Lengyel 2001; Porter 2000; Sölvell 2009). A klaszterek gyakran több iparág szereplőit foglalják magukba, különböző, de olyan egymást kiegészítő vállalatokból állnak, amelyek az értékláncban egy konkrét kapcsolatra vagy tudásbázis köré specializálódnak (EC 2009; OECD 1999; Vas 2009). A klasztereket Porter közismert fogalmán kívül (Porter 2000, 254.), többek között Asheim és szerzőtársai $(2011,879$.) is úgy definiálják mint az „ugyanazon vagy egymáshoz közeli (integrált) iparágak egymástól kölcsönösen függő vállalkozásainak koncentrációja egy kisebb földrajzi területen". Tehát a klaszterek versenyelőnyeinek egyik meghatározó forrása a földrajzi közelség. ${ }^{1}$ 
A földrajzi közelség ösztönzően hat az információ és a tudás áramlására és az új ötletek megszületésére (Boschma 2005; Lengyel, Fenyővári, Nagy 2012). A vállalatok térbeli tömörülésüknek köszönhetően agglomerációs előnyökben részesülhetnek, amelyek növelik a vállalati hatékonyságot és innovativitást, valamint annak lehetőségét, hogy alacsonyabb egységköltségen, alacsonyabb szállítási és tranzakciós költségek mellett szerezzék be inputjaikat. A regionális klaszter olyan rugalmas specializáció lehetőségét nyújtó szerveződés, amelyben a szereplők a földrajzi közelség előnyeit sikeresen kamatoztatják.

A földrajzi közelségből eredő előnyök három típusát különböztetjük meg, amelyek megegyeznek az agglomerációs előnyök Isard-féle tipizálásával. Az agglomerációs előnyök - lényegében térbeli külső méretgazdaságossági előnyök - akkor jönnek létre (és a vállalkozások a pozitív extern hatások következtében akkor képesek költségeiket csökkenteni), ha nagyszámú és specializált munkaerő áll rendelkezésre, ha az üzleti partneri hálózat kiépült és ha megfelelő színvonalú az infrastruktúra (Lengyel, Szanyi 2011). Az agglomerációs előnyök széles körben elfogadott típusai a nagyvállalati (újabban tevékenységkomplexitási), a lokalizációs és az urbanizációs előnyök (Beaudry, Schiffauerova 2009; Capello 2007; Lengyel, Rechnitzer 2004). Utóbbi kettő alkalmas a klaszteresedés elősegítésére. A lokalizációs agglomerációs előnyök (másképpen Marshall-Arrow-Romer, azaz MAR extern hatások) külsők a vállalatok, de belsők az adott iparág számára, ugyanazon iparághoz tartozó vállalkozások térbeli koncentrációjából, földrajzi közelségéből erednek, valamint főleg a specializációra alapoznak. Az urbanizációs agglomerációs előnyök (másképpen Jacobs-féle extern hatások) külsők egy iparág és annak vállalatai számára, és több iparág egy régióban való elhelyezkedéséből erednek. Az urbanizációs előnyök inkább a több húzóágazattal bíró, nagy népsűrűségű nagyvárosi térségekben figyelhetők meg, míg a lokalizációs előnyök főleg a kisvárosi térségekben, ahol a gazdasági szereplők és az intézetek köre jóval szűkebb.

A klasztereket számos szempont szerint csoportosíthatjuk (Lengyel 2001). Philip McCann (Iammarino, McCann 2006; McCann 2008, 2013) a klaszterek újszerü tipizálását adja meg, melynek előnye, hogy konkrét gazdaságfejlesztési célok megfogalmazásakor jobban alkalmazható, hiszen megnevezi mindazokat a jellemzőket, amelyeket az egymástól eltérő klaszterek menedzselése során figyelembe kell venni. McCann a klaszterek három típusát különbözteti meg, figyelembe véve a vállalatok klaszterben betöltött szerepét és kapcsolatát, a klaszterek dinamikáját, a tranzakciós költségeket minimalizáló vállalati törekvéseket és a kiaknázható agglomerációs előnyöket. Ezek a tiszta agglomerációk, az iparági komplexumok és a társadalmi hálózatok (1. táblázat). A valóságban mindhárom ideáltípus jellemzői keveredhetnek egy-egy klaszterben, de általában megadható, hogy melyik típus a domináns.

A tiszta agglomerációra épülő klaszterekben egyik vállalat sem bír meghatározó piaci befolyással és a jobb piaci alkupozíció elérésének érdekében a partnerkapcsolatok folyton változó körére építenek, ami még intenzívebbé teszi a 
1. táblázat: A klaszterek típusai és jellemzői az agglomerációs előnyök alapján Cluster types based on agglomeration advantages

\begin{tabular}{|c|c|c|c|}
\hline Jellemzők & Tiszta agglomeráció & Iparági komplexum & $\begin{array}{l}\text { Társadalmi hálózat: } \\
\text { új/régi }\end{array}$ \\
\hline Cégek mérete & Atomisztikus & Néhány nagy cég & Változó \\
\hline \multirow{4}{*}{$\begin{array}{l}\text { Kapcsolatokjel- } \\
\text { lemzői }\end{array}$} & Nem azonosítható & Azonosítható & Bizalom, lojalitás \\
\hline & Széttöredezett & Stabil & Közös lobbizás \\
\hline & Instabil & Gyakori & Közös cégek \\
\hline & & & Nem opportunista \\
\hline Tagság & Nyitott & Zárt & Részben nyitott \\
\hline Dinamika & Véletlenszerü & Stratégiai & Vegyes \\
\hline \multirow{3}{*}{$\begin{array}{l}\text { Technológiai } \\
\text { irány }\end{array}$} & Folyamatorientált & Komplex termékorientált & Új: radikálisan újter- \\
\hline & Problémamegoldó & Költségcsökkentő & mék-orientált \\
\hline & & & $\begin{array}{l}\text { Régi: folyamatorientált, } \\
\text { vásárlóvezérelt }\end{array}$ \\
\hline \multirow{2}{*}{$\begin{array}{l}\text { Innováció for- } \\
\text { rása }\end{array}$} & Külső a cégnek & Belső a cégnek & Új: vegyes \\
\hline & & & Régi: külső a cégnek \\
\hline \multirow{2}{*}{$\begin{array}{l}\text { Klaszterhez csat- } \\
\text { lakozás }\end{array}$} & Ingatlanbérlés & Hosszú távú befektetés & Történelmi, tapasztalati \\
\hline & $\begin{array}{l}\text { Letelepedéssel együtt } \\
\text { jár }\end{array}$ & Letelepedéssel együtt jár & $\begin{array}{l}\text { Letelepedés szükséges, } \\
\text { de nem elegendő }\end{array}$ \\
\hline Térbeli hatások & $\begin{array}{l}\text { Bérleti díj megemelke- } \\
\text { dése }\end{array}$ & Nincs hatása a bérleti díjra & $\begin{array}{l}\text { Bérleti díj részleges tő- } \\
\text { késítése }\end{array}$ \\
\hline \multirow[t]{2}{*}{$\begin{array}{l}\text { Szabályozás } \\
\text { módja }\end{array}$} & Piaci & Hierarchikus & $\begin{array}{l}\text { Új: kapcsolati és kogni- } \\
\text { tív hálózatok }\end{array}$ \\
\hline & & & $\begin{array}{l}\text { Régi: társadalmi és tör- } \\
\text { ténelmi hálózatok }\end{array}$ \\
\hline Példák klaszterre & $\begin{array}{l}\text { Versenyző városi gazda- } \\
\text { ság - London (pénzügy, } \\
\text { bank, biztosítás, üzleti } \\
\text { szolgáltatások) }\end{array}$ & $\begin{array}{l}\text { Acélipar, vegyipar, autóipar, } \\
\text { gyógyszeripar, gépipar, orvosi } \\
\text { műszerek, IKT hardver }\end{array}$ & $\begin{array}{l}\text { Új: „Szilícium mocsár” } \\
\text { (Cambridge), IKT (Oulu) } \\
\text { Régi: olasz iparági kör- } \\
\text { zetek }\end{array}$ \\
\hline $\begin{array}{l}\text { Agglomerációs } \\
\text { előnyök }\end{array}$ & Urbanizációs előnyök & $\begin{array}{l}\text { Tevékenységkomplexitási elő- } \\
\text { nyök }\end{array}$ & Lokalizációs előnyök \\
\hline Térszerveződés & Nagyvárosi & $\begin{array}{l}\text { Lokális vagy regionális, de nem } \\
\text { nagyvárosi }\end{array}$ & $\begin{array}{l}\text { Lokális vagy regionális, } \\
\text { de nem nagyvárosi }\end{array}$ \\
\hline
\end{tabular}

Forrás: saját szerkesztés Iammarino, McCann (2006, 1029.), McCann (2008, 31.) alapján.

helyi versenyt (pl. londoni pénzügyi klaszter). A versenyelőnyök elsősorban a vállalatok térbeli elhelyezkedéséből adódnak, a lokális pozitív extern hatásokból erednek. A vállalatok technológiai fejlesztései folyamatorientáltak, az innováció forrása is jellemzően külső. A klasztertagok közötti kapcsolatrendszer véletlenszerüen alakul, széttöredezett, instabil, ugyanakkor nyitott, ami hozzájárul az ingatlanbérlések számának növekedéséhez és a bérleti díjak emelkedéséhez. Az ilyen típusú klaszterek jellemzően a nagyvárosi térségekben jönnek létre, ahol a szereplők urbanizációs agglomerációs előnyökben részesülnek. 
Az iparági komplexumokban a klaszterek vállalatai hosszú távú és stabil kapcsolatrendszerre építenek (pl. a medium-high-tech és high-tech feldolgozóipari tevékenységek: autóipar, vegyipar), meghatározóak a stratégiai együttműködések. A klasztert néhány helyi székhelyű vállalat dominálja, a partnerek a földrajzi közelséget a tranzakciós költségek minimalizálására hasznosítják. A vállalatok innovációs tevékenységük folytatására saját kutatórészlegeket müködtetnek, céljuk, hogy fejlesztéseik révén új, komplex termékeket állítsanak elő. A vállalatok a klaszter tagjává jelentős befektetések (fizikai tőkébe, ingatlanba stb.) árán válhatnak, általában a tagok üzleti, szerződéses kapcsolatban állnak egymással. A vállalati hierarchia erős. Az ilyen típusú klaszterek főleg kisebb városi térségekre jellemzők, nem pedig nagyvárosiakra, azaz főleg lokalizációs agglomerációs előnyökre támaszkodnak.

A társadalmi hálózat olyan klasztertípus, amely bizalmi alapú, „nem üzleti" kapcsolatrendszerként írható le. A klasztertagok között meghatározók az informális, személyes kapcsolatokon, a közös értékeken, az azonos kulturális háttéren, a történelmi gyökereken alapuló együttműködések. Mindezek döntően egyrészt a régi társadalmi hálózatként ismert rugalmas specializációjú tevékenységek klaszterei (pl. olasz iparági körzetek), másrészt az új társadalmi hálózatként leírható, például high-tech klaszterek esetében fontosak, ahol nélkülözhetetlen a bizalom, az együttműködési készség, egymás elfogadása és a kockázatvállalás. Az új társadalmi hálózatokban lévő vállalatok célja a radikális innováció, amelynek sikere a szereplők kapcsolati, leginkább kognitív közelségén alapszik. A klaszterben a szereplők szoros kapcsolati hálót hoznak létre, és nem feltétlenül szerződések alapján történnek az együttműködések. Ezzel szemben a régi társadalmi hálózatok esetében a fogyasztók igényeihez igazodva a meglévő technológiák fejlesztésén van a hangsúly. A vállalatok között verseny és együttműködés együttesen megfigyelhető, az együttmüködések leginkább a társadalmi közelségnek köszönhetően jönnek létre. Az új és a régi társadalmi hálózatok regionális vagy lokális, de nem nagyvárosi kiterjedésűek és szintén lokalizációs agglomerációs előnyöket hasznosítanak.

A fenti típusok megkülönböztetésének alapja tehát leginkább a vállalati méret, a klasztertagok közötti kapcsolatok természete, a klaszter dinamikája és a kapcsolati közelség mértéke, az innovációs tevékenységek jellege, amely jellemzők egyben eltérő fejlesztési lehetőségekre is utalnak. Az, hogy a klaszterek hol jöhetnek létre, nagymértékben függ a helyet adó térség sajátosságaitól és az agglomerációs előnyök milyenségétől. A magyarországi városrégiókban lévő potenciális feldolgozóipari klasztereket elsősorban a vállalatok száma és mérete, valamint a gazdasági tevékenység jellege alapján (high-, medium-high- vagy low-tech) vizsgáljuk. A vállalatok közötti kapcsolatok mértékére és milyenségére nem térünk ki. 


\section{A városrégiók és a feldolgozóipar jelentősége Magyarországon}

Amint a bevezetőben kitértünk rá, napjainkra a lokalitás szerepe felértékelődött. A térszerkezet átalakulásának, a térbeli koncentrációs folyamatok felismerésének hatására felerősödött a városrégiók, városi településegyüttesek gazdasági szerepének vizsgálata, a policentrikus városhálózatok dinamikájának elemzése és ezen alapuló gazdaságfejlesztési lehetőségeik kiaknázása (Rechnitzer, Smahó 2011). Az Európai Unió regionális és kohéziós politikájában 2014-2020 között is kiemelt program a városok és vonzáskörzetük integrált fejlesztése.

Az 1970-es évek óta Magyarországon számos kísérlet történt a városi térségek lehatárolására. Az általunk figyelembe vett lehatárolás a 2001-es népszámlálási adatok alapján készült 2003-ban, és a Központi Statisztikai Hivatal kifejezését használva 21 nagyvárosi településegyüttest definiál (Kovács, Tóth 2003). 2014-ben a 2011-es népszámlálási adatok alapján korrigálták a városi településegyüttesek kiterjedését és körét (Tóth 2014), de tekintettel arra, hogy a feldolgozóipari tevékenységek városrégiókban való súlyát korábbi adatok alapján elemezzük, ezért a 2003-as területbeosztást alkalmazzuk.

Kutatásunkban összesen 20 városrégiót vizsgálunk, amelyek vonzáskörzete saját megyéjén belül van (Budapestnek Pest megyén belül), azaz vonzáskörzeteik nem lépik át a megyehatárokat. A balatoni településegyüttest nem vesszük figyelembe egyedi sajátossága miatt: vitatható csomóponti jellege, hiszen például nincs egyetlen domináns központja.

A városi településegyüttesek alkalmazásának nagy előnye a településekkel, járásokkal szemben, hogy a napi térpályát, a tényleges térbeli lakossági, üzleti, munkaerő-kapcsolatokat tükrözik. Főleg Budapest esetében jelentős a vonzáskörzet, amelynek hiányában torz eredmények születnének. A nagyobb területi aggregációs szint választása alkalmasabb lehet a vállalati hálózatok kiterjedésének vizsgálatára, de amennyiben az alkalmazottak száma alapján kívánjuk a klasztereket feltérképezni, érdemes egy várost és annak munkaerő-vonzáskörzetét mint területi szintet választani.

A városi településegyüttesek súlya az országban kiemelkedő (Szilágyi 2014). A magyar lakónépesség 52\%-a él itt, és az elmúlt egy évtized alatt ezek a településegyüttesek voltak a belső migráció célpontjai. Miközben a településegyüttesek központjaiban (és társközpontjaiban) csak 1\%-kal nőtt a lakosságszám, addig a településegyüttesekbe tartozó egyéb településeken 12\%-kal (KSH 2012a). Azaz valójában a vonzáskörzetek lakossága abszolút értelemben gyarapodott.

Ezek a városi településegyüttesek, összhangban a lakosság vonzásával, egyúttal gazdasági csomópontok is. Az agglomerációs központokban működő vállalkozások ezer lakosra jutó száma kiemelkedő, főleg a működő társas vállalkozásoké ( $61 \mathrm{db}$, miközben országosan 39 db). Nemcsak a központokban, azaz a városokban, hanem vonzáskörzetükben is igen sok vállalat müködik, nagyjából az országos átlagnak megfelelően. Az egy adófizetőre jutó szja-alapot képező jövedelem a központokban 20\%-kal magasabb az országos átlagnál. A nyilván- 
tartott álláskeresők aránya a munkaképes korú népességből is jóval alacsonyabb a településegyüttesekben: a központokban 5,5\% és a településegyüttesek egyéb településein $6,4 \%$, miközben az országos átlag $8,4 \%$.

A városi településegyüttesek gazdasági-társadalmi súlyát jól mutatja a népességen belül a diplomások aránya. Az összes városi településegyüttes közül ötben a diplomások aránya nem éri el az országos értéket (19\%-ot), de a többi településegyüttesben ez az érték 20 és $25 \%$ közötti. A településegyüttesek központjaiban a diplomások aránya ennél is magasabb, de egyedül Budapesten haladja meg a 30\%-ot. Ezzel párosul, hogy a 20 vizsgált városi településegyüttes többsége egyetemi vagy főiskolai központ, tehát biztosítva van a régióban a diplomás munkaerő újratermelődése, többek között a feldolgozóipar számára is.

A feldolgozóiparnak a városrégiók gazdaságában betöltött szerepéről eddig keveset tudtunk, az azonban ismert, hogy Magyarországon a feldolgozóiparra komoly hatást gyakorolt az 1990-ben bekövetkezetett rendszerváltás, amelynek egyik legfontosabb eleme a privatizáció volt (Barta 2002; Kiss 2010). Az országban megjelentek a tőkeerős, fejlett technológiával rendelkező külföldi vállalatok, az ezredfordulóra a feldolgozóiparban a jegyzett tőke közel 70\%-a külföldről származott. A külföldi működő tőke részben a kedvezőbb költségek, részben a felvevőpiacok, részben az egyedi termelési tényezők (pl. felkészült munkaerő) miatt települt Magyarországra. A magyar ipar, így a feldolgozóipar további átalakulását indította el, hogy 2000-től az EU-val lehetővé vált a szabad kereskedelem, továbbá 2004-ben az ország az Európai Unióhoz csatlakozott. A feldolgozóipar GDP-ből való részesedése 2004-et követően mindvégig 21-22\% körül mozgott.

A feldolgozóipar helyzetéről részletesebb képet a feldolgozóipar alágainak figyelembevételével kapunk. Vizsgálatukat az alkalmazottak száma és az exportértékesítés alapján végezzük el, a 2005-ös és a 2010-es évre. E két év elemzésének célja annak kiderítése, hogy az EU-csatlakozás, valamint a válság hatással volt-e a feldolgozóipar városrégiókban való súlyának alakulására és így a potenciális feldolgozóipari klaszterek létrejöttére. Másképp megfogalmazva feltárjuk, hogy mely gazdasági tevékenységek voltak képesek kritikus tömeget elérni és megtartani. Azért is érdemes egy évtizedre visszatekinteni, mivel egy klaszter létrejötte legalább tíz évet vehet igénybe.

A feldolgozóipar magyar gazdaságban betöltött szerepét ezen évek vizsgálatával jól szemléltethetjük. A 2005-2010-es időszakban az alkalmazottak számában változások következtek be a feldolgozóiparban. A válság hatására a feldolgozóiparban alkalmazásban állók száma a 2005-ös 692 ezer főről 2010-re csaknem 600 ezer före csökkent (KSH 2010a). Egészen a válságig az összes alág közül a legtöbb föt a villamos berendezés gyártása (CJ) alkalmazta (közel 133 ezer föt), azt követően azonban az alkalmazottak száma jelentősen visszaesett (2010-re 37 ezer före). ${ }^{2}$ 2010-ben a legtöbb föt az élelmiszer, ital, dohány gyártása (CA) alkalmazza (2010-ben 95 ezer fót, a feldolgozóiparban alkalmazottak 16\%-át), de jelentős még a fémalapanyag és fémfeldolgozási termék gyártásában $(\mathrm{CH})$ és a jármügyártásban $(\mathrm{CL})$ dolgozók száma is (1. ábra). Mindkét utóbbi 
1. ábra: Az alkalmazottak megoszlása a feldolgozóiparban, 2010 Distribution of employees in the manufacturing sector, 2010

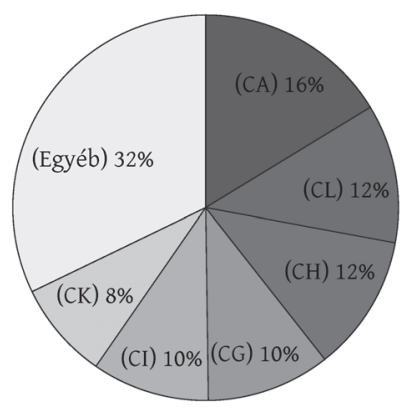

(CA) Élelmiszer, ital, dohánytermék gyártása

( (CL) Jármügyártás

$\square(\mathrm{CH})$ Fémalapanyag és fémfeldolgozási termék gyártása

$\square$ (CG) Gumi-, műanyag és nemfém ásványi termék gyártása

$\square$ (CI) Számítógép, elektronikai, optikai termék gyártása

$\square$ (CK) Gép, gépi berendezés gyártása

$\square$ Egyéb (CB, CC, CD, CE, CF, CJ, CM)

Adatok forrása: KSH (2010b).

alágban 2010-ben közel 67 ezer föt alkalmaztak, így e két alág a feldolgozóiparban alkalmazottak csaknem egynegyedét adja. Jelentős ezen kívül a gumi-, müanyag és nemfém ásványi termék gyártásában (CG) és a számítógép, elektronikai, optikai termék gyártásában (CI), valamint a gép, gépi berendezés gyártásában (CK) alkalmazottak száma is. Ez utóbbi alág az alkalmazottak 8\%-át, az előbbi két alág 10-10\%-át alkalmazza a feldolgozóiparban dolgozó munkaerőnek. További alágak a feldolgozóiparban alkalmazottak 6-7\%-át (CB, CC, CJ, CM), illetve 1-3\%-át (CD, CE, CF) adják. Az adatok alapján az is megállapítható, hogy az összes alág közül a számítógép, elektronikai, optikai termék gyártása (CI) és a jármügyártás (CL) tudta a legnagyobb mértékben növelni az alkalmazottak létszámát.

A feldolgozóiparban az export az összes értékesítésen belül bármely évet vizsgálva magas értéket ért el, ráadásul 2005 óta az exportértékesítés aránya folyamatosan növekedett. 2010-ben a magyar feldolgozóipar összes értékesítésének 70,2\%-át az export tette ki. 2005-ben a termelésének legalább 75\%-át exportálta 3 alág (CI, CJ, CL), míg 2010-ben már 6 alág (CC, CD, CG, CK, CL, CM).

A 2004-es EU-csatlakozást követő években végig a feldolgozóipari exportértékesítés közel $30 \%$-át a számítógépgyártás (CI), egynegyedét a járműgyártás (CL) adta, azaz együttesen e két alágból származott ezekben az években a magyar feldolgozóipar exportjának több mint fele. A válságot követően a feldolgozóiparban az exportértékesítés aránya növekedett: 2010-re 12 alágban nőtt az export aránya, egyedül az egyéb feldolgozóipar; ipari gép, berendezés üzembe helyezése, javítása (CM) esetében csökkent.

Összességében látható, hogy a feldolgozóipari alágak közül néhány kiemelkedik: az élelmiszer, ital, dohánytermék gyártása (CA), amely az összes alág közül a legtöbb főt alkalmazza, valamint a számítógép, elektronikai, optikai termék gyártása $(\mathrm{CI})$ és a járműgyártás $(\mathrm{CL})$, amely alágak a feldolgozóiparban az 
export jelentős hányadát adják és fontos szerepük van a foglalkoztatásban is. Ezen kívül a gumi-, műanyag és nemfém ásványi termék gyártása (CG) és a gép, gépi berendezés gyártása (CK) említésre méltó az alkalmazottak számát és az exportértékesítést együttesen tekintve.

\section{A klaszterek feltérképezésének módszertana}

A továbbiakban a 13 feldolgozóipari alág térbeli sajátosságait tárjuk fel, megvizsgáljuk azok Magyarország városrégióiban való földrajzi koncentrációját és kritikus tömegének meglétét. Felmérésünkben az European Cluster Observatory (www.clusterobservatory.eu) módszertanát vesszük át, amelyet az Európai Unióban lévő klaszterek szisztematikus feltérképezésére alkalmaznak. A módszertan előnye, hogy alkalmazottak számának adataira építve, objektív módon képes felmérni a potenciális klaszterek kritikus tömegét. A klaszterfeltérképezés három kritérium - az European Cluster Observatory terminológiáját használva a méret, a specializáció és a fókusz - alapján történik. Attól függően, hogy a potenciális klaszter hány kritériumnak felel meg, 0, 1, 2, vagy 3 csillaggal értékeljük azokat. ${ }^{3}$

Az első kritérium a méret. Ha egy adott városrégióban lévő iparág (klaszter) alkalmazottainak száma a városrégiók összes alkalmazottjának jelentős hányadát teszi ki, akkor nagyobb a valószínűsége annak, hogy az iparág (a klaszter) jelentős gazdasági hatással bír. Ha egy adott városrégióban lévő iparág (klaszter) az összes vizsgált városrégióban lévő klaszter közül a legjobb 10\%-ba kerül, akkor egy csillagot kap.

A második kritérium a specializáció. Ennek vizsgálata azért fontos, mert ha egy városrégió egy adott iparágra (klaszterre) a nemzetgazdaság egészéhez képest (esetünkben az összes városrégióhoz képest) jobban specializálódott, akkor ez arra utalhat, hogy a klaszter gazdasági hatásai olyan erősek, hogy a klaszter képes más, kapcsolódó tevékenységeket vonzani a térségbe. A térség adott iparágának városi térségen belüli relatív helyzetét és a térség specializációját a lokációs hányadossal (LQ) mérhetjük. A lokációs hányados számítása a nemzetközi és a hazai szakirodalomban is gyakran alkalmazott módszere a potenciális húzóágazatok, klaszterek feltérképezésének (EC 2009; Gecse, Nikodémus 2003; Miller, Botham, Gibson, Martin, Moore 2001; Szakálné Kanó 2011; Vas 2009), hiszen ahogyan több kutatás is mutatja: számos gazdasági tevékenység a térben koncentrálódik (Rédei, Jakobi, Jeney 2002).

A lokációs hányados többféle alapadat segítségével számolható. Esetünkben az iparágak alkalmazottjainak városrégiókban való koncentrációját akarjuk mérni az összes városrégió viszonylatában, ezért a lokációs hányadost (LQ) az alábbi módon számoljuk ki:

$$
L Q=\left(E_{i j} / E_{j}\right) /\left(E_{i n} / E_{n}\right),
$$


ahol $E_{\mathrm{ij}}$ a j-edik városrégióban az i-edik iparágban alkalmazottak számát, $\mathrm{E}_{\mathrm{j}}$ a j-edik városrégió alkalmazottjainak számát, $\mathrm{E}_{\mathrm{in}}$ az összes városrégióban az i-edik iparágbeli alkalmazottak számát, $\mathrm{E}_{\mathrm{n}}$ pedig az összes városrégió összes alkalmazottjának számát jelenti.

A lokációs hányadosból következtethetünk egy adott gazdasági tevékenységnek a térség gazdaságában betöltött szerepére. Koncentrációról akkor beszélhetünk, ha a lokációs hányados értéke nagyobb 1-nél (Patik, Deák 2005). Ekkor az adott városrégióban a vizsgált gazdasági tevékenységnek a városrégiók összességéhez viszonyítva magasabb földrajzi koncentrációjára következtethetünk. Az European Cluster Observatory a klaszterfeltérképezés során a lokációs hányados nagyobb minimumértékét határozta meg: egy csillagot kapnak azok a feldolgozóipari alágak, ahol LQ $\geq 2$. Kutatásunkban tehát a feldolgozóipari alágak súlyát vizsgáljuk a városrégiók területi szintjén, de nemcsak feldolgozóiparon belül, hanem az összes gazdasági tevékenységhez viszonyítva.

Végül a harmadik kritérium a fókusz. Ha egy iparág (klaszter) az adott városrégióban lévő összes alkalmazott jelentős hányadát teszi ki, akkor nagyobb a valószínűsége a tudástúlcsordulásnak, a tapasztalatok elterjedésének és az együttműködéseknek. A regionális fókusz vizsgálatával kiderül, hogy egy városrégió mennyire fókuszál egy iparági (klaszter) tevékenységre. Azon első 10\%-ba tartozó iparágak (klaszterek), amelyek a városrégiókban az alkalmazottak legnagyobb hányadát teszik ki, további egy csillagot kapnak.

A városrégiók feldolgozóiparának vizsgálata a három kritérium szerint a 2005. és 2010. évi alkalmazottak száma alapján történik. Az adatok forrásául a Központi Statisztikai Hivatal Cég-Kód-Tár (KSH 2005, 2010b) kiadványa szolgál, amely a vállalkozások székhely szerinti adatait tartalmazza. A pontos vállalati létszámadatok hiányában a nemzetközi gyakorlatot követve az adatokat becsülni kellett. Feltételezve, hogy az egyes létszám-kategóriákon belül a vállalatok száma egyenletesen oszlik el, minden létszámadatot a saját létszám-kategóriáján belüli értékek számtani átlagával helyettesítjük (Ellison, Glaeser 1997; Szakálné Kanó 2011).

\section{A feldolgozóipari klaszterek feltérképezésének eredménye}

A feldolgozóipari tevékenységek várostérségben való súlyának feltárásakor összetett képet kapunk. Az elemzés rávilágít arra a hazai sajátosságra, hogy mindegyik feldolgozóipari alág minimális súlya kimutatható a budapesti településegyüttesben, mégpedig a méret alapján, de egyetlen két- vagy háromcsillagos potenciális feldolgozóipari klaszter jelenléte sem érzékelhető (2. táblázat). Továbbá három alág (CD, CE, CF) alkalmazottak számában mért koncentrálódása csak Budapest térségében mutatható ki. Ezen értékek mögött egyértelműen a fővárosi térség társadalmi és gazdasági súlya húzódik meg, hiszen a térség a hazai GDP körülbelül 40\%-át állítja elő és a lakosság negyede él itt. 
2. táblázat: Potenciális feldolgozóipari klaszterek a városrégiókban Potential manufacturing clusters in the Hungarian urban areas

\begin{tabular}{|c|c|c|c|c|c|c|c|c|c|c|c|c|c|c|}
\hline \multicolumn{2}{|l|}{ Várostérség és év } & $C A$ & $C B$ & $C C$ & $C D$ & $C E$ & $C F$ & $C G$ & $\mathrm{CH}$ & $C I$ & CJ & $C K$ & $C L$ & $C M$ \\
\hline \multirow[t]{2}{*}{ Budapesti } & 2005 & $*_{--}$ & $*_{--}$ & *-- & $*_{--}$ & *-- & $*_{--}$ & $*_{--}$ & $*_{--}$ & $*_{--}$ & $*_{--}$ & $*_{--}$ & $*_{--}$ & $*_{--}$ \\
\hline & 2010 & $*_{--}$ & *-- & $*_{--}$ & $*_{--}$ & $*_{--}$ & $*_{--}$ & $*_{--}$ & $*_{--}$ & $*_{--}$ & $*_{--}$ & $*_{--}$ & $*_{--}$ & $*_{--}$ \\
\hline \multirow[t]{2}{*}{ Győri } & 2005 & & & & & & & $*_{--}$ & $*_{--}$ & & & -** & $* * *$ & \\
\hline & 2010 & & & & & & & $* *_{-}$ & $*_{--}$ & & & & $* * *$ & \\
\hline \multirow[t]{2}{*}{ Miskolci } & 2005 & & & & & & & & $* * *$ & & & & & \\
\hline & 2010 & & & & & & & & $* * *$ & & & & & \\
\hline \multirow[t]{2}{*}{ Pécsi } & 2005 & & & & & & & & & & & & & \\
\hline & 2010 & & $-*$ & & & & & & & $-*$ & & & & \\
\hline \multirow[t]{2}{*}{ Egri } & 2005 & & & & & & & & & $-*$ & $-*$ & & & \\
\hline & 2010 & & -* & & & & & & & $-*$ & $-*$ & -** & $-* *$ & \\
\hline \multirow[t]{2}{*}{ Szombathelyi } & 2005 & & & -* & & & & & & $* *_{-}$ & -** & & -*_ $_{-}$ & $-{ }^{*}$ \\
\hline & 2010 & & $-*$ & & & & & & & $* * *$ & -* $_{-}$ & & $-* *$ & $-*$ \\
\hline \multirow[t]{2}{*}{ Zalaegerszegi } & 2005 & $-* *$ & & & & & & & & & & & & --* \\
\hline & 2010 & & $-*$ & & & & & & $-* *$ & $-*$ & & & & \\
\hline \multirow[t]{2}{*}{ Békéscsabai } & 2005 & $-* *$ & & & & & & & & & & & & $--*$ \\
\hline & 2010 & $-* *$ & $-*$ & -* & & & & & & $-*$ & & & & $-*$ \\
\hline \multirow[t]{2}{*}{ Debreceni } & 2005 & $*_{--}$ & -*_ $_{-}$ & & & & $-*$ & & & & & & & --* \\
\hline & 2010 & $*_{--}$ & & & & & -*_ & & & & & & & \\
\hline \multirow[t]{2}{*}{ Kaposvári } & 2005 & & & & & & & & & & & & & --* \\
\hline & 2010 & $-* *$ & & & & & & & & & -** & & & \\
\hline \multirow[t]{2}{*}{ Kecskeméti } & 2005 & $* * *$ & & $-*$ & & & & & & $-*$ & -* $_{-}$ & & & \\
\hline & 2010 & $* * *$ & & $-*$ & & & & & & & $-_{-}^{*}$ & & & \\
\hline \multirow[t]{2}{*}{ Nyíregyházi } & 2005 & $-* *$ & & & & & & $* * *$ & & & & & & \\
\hline & 2010 & & $-*$ & & & & & $* * *$ & & $-*$ & & & & -*_ \\
\hline \multirow[t]{2}{*}{ Salgótarjáni } & 2005 & & & & & & & $-*$ & $-*$ & & -** & $-* *$ & & \\
\hline & 2010 & & & & & & & $-*$ & $-* *$ & & -** & & & \\
\hline \multirow[t]{2}{*}{ Soproni } & 2005 & & $-*$ & & & & & & & & & & & $-{ }^{*}$ \\
\hline & 2010 & -*_ & & & & & & & & & & & & -** \\
\hline \multirow[t]{2}{*}{ Szegedi } & 2005 & $* * *$ & & & & & & & & & & & & $-{ }^{*} *$ \\
\hline & 2010 & $* * *$ & $-*$ & & & & & & & $-*$ & & & & \\
\hline \multirow[t]{2}{*}{ Szekszárdi } & 2005 & & -*_ & & & & & & & -* & & & & --* \\
\hline & 2010 & $-* *$ & -* & & & & & & & $-*$ & -* $_{-}$ & & & \\
\hline \multirow[t]{2}{*}{ Székesfehérvári } & 2005 & & & & & & & & $* *_{-}$ & $* *_{-}$ & & -** & $* *_{-}$ & $-* *$ \\
\hline & 2010 & & & & & & & & $* * *$ & $*_{--}$ & & & $* * *$ & \\
\hline \multirow[t]{2}{*}{ Szolnoki } & 2005 & & -** & & & & & & & & & & & --* \\
\hline & 2010 & $-* *$ & -** & & & & & & & $-*$ & & & & \\
\hline \multirow[t]{2}{*}{ Tatabányai } & 2005 & & & & & & & $*_{--}$ & & $* *_{-}$ & -* $_{-}$ & $*_{--}$ & & --* \\
\hline & 2010 & & & & & & & $* * *$ & & $*_{-} *$ & & $* * *$ & & \\
\hline \multirow[t]{2}{*}{ Veszprémi } & 2005 & & & & & & & $-*$ & & & -* $_{-}$ & & -*_ & \\
\hline & 2010 & & & & & & & $-* *$ & & --* & $-*_{-}$ & -*_ & & \\
\hline
\end{tabular}

Megjegyzés: A cellák adatai sorrendben: méret, specializáció, fókusz. 
A kapott eredmények alapján a feldolgozóipari alágak Magyarország vidéki városrégióiban elért kritikus tömegéről vegyes kép rajzolódik ki. A 13 vizsgált feldolgozóipari alág közül a 2010-es eredmények alapján hat esetben figyelhető meg, hogy azok a klaszterfeltérképezés mindhárom kritériumának megfelelnek, tehát valamely városrégióban potenciális klaszterek. Ezek az élelmiszer, ital, dohánytermék gyártása (CA), a gumi-, műanyag és nemfém ásványi termék gyártása (CG), a fémalapanyag és fémfeldolgozási termék gyártása $(\mathrm{CH})$, a számítógép, elektronikai, optikai termék gyártása $(\mathrm{CI})$, a gép, gépi berendezések gyártása (CK) és a járműgyártás (CL). Ezeknek az iparágnak a gazdasági súlya (még ha eltérő mértékben, de) a 2005-ös évben is kimutatható, ezért a továbbiakban e 6 alág térbeli klasztereinek elemzésére fókuszálunk. A kiemelt alágak klaszteresedésének elemzéséhez a 2010-es adatok részletesen rendelkezésre állnak (1., 2., 3. melléklet).

Az egyik meghatározó feldolgozóipari tevékenység az élelmiszer, ital, dohánytermék gyártásának alága (CA), amely a városrégiók felében ért el legalább egy csillagot valamelyik évben. Az eredmények rámutatnak arra, hogy Magyarország „éléskamrája” a Dél-Alföld régió és annak városrégiói: Szeged és Kecskemét. E két városrégió a feldolgozóipari tevékenységek közül egyértelműen az élelmiszeriparra specializálódott (LQ $\geq 3$ ), az alkalmazottak több mint 12\%-át adja Szeged és 10\%-át Kecskemét (3. táblázat). Az élelmiszeripar e térségek hagyományos ipara, olyannyira meghatározó, hogy ágazatai (húsipar, konzervipar, paprikafeldolgozás, malomipar, tejipar, sütőipar) mind meghonosodtak a térségben. Az élelmiszer-ipari vállalatok mérete változó. Szeged térségében az összes (több mint 60) vállalkozás közül kettő olyan van, amely 1000 főnél is többet alkalmaz. Kecskeméten is a közel 100 vállalkozás közül három alkalmaz legalább 250 föt.

Ezeken a térségeken kívül a 2010-es adatok alapján kiemelkedik még a békéscsabai, szigetszerủen a szekszárdi és a szolnoki városrégió. De bármely említett városrégiót is vizsgáljuk, többségében ugyanazzal az intézményi, társadalmi és kulturális háttérrel rendelkező, főleg magyar tulajdonban lévő, lokalizációs előnyökben részesülő vállalatok dominálnak (pl. a Pick Szeged Zrt. Szegeden, a Kecskeméti Konzervgyár Zrt. Kecskeméten, a Csabahús Kft. Békéscsabán, a Kométa 99 Zrt. húsipari vállalat vagy a Magyar Cukor Zrt. Kaposváron). Az is megállapítható, hogy a válság az élelmiszeripart is átrendezte: meggyengült Zalaegerszegen és Nyíregyházán, míg megerősödött Kaposvárott, Szekszárdon és Szolnokon.

A gumi-, müanyag és nemfém ásványi termék gyártása (CG) alág gazdasági súlya összesen öt városrégióban mutatható ki legalább kétcsillagos potenciális klaszterként. Ezek közül a 2010-es adatok alapján két térség, a tatabányai és a nyíregyházi városrégió emelkedik ki. Mindkét térségben a munkavállalók 8\%-a ebben az iparágban dolgozik, és a városrégiók specializáltságát jól mutatja, hogy Tatabányán $L Q=3,71$, Nyíregyházán $L Q=3,53$. E két térségben lévő iparági vállalatok többsége kisvállalkozás, csak néhány olyan vállalat van, amely akár több mint 300 föt alkalmaz. 
3. táblázat: Háromcsillagos potenciális klaszterek méret, specializáció és fókusz szerint Three stars potential clusters according to size, specialisation and focus

\begin{tabular}{lcccc}
\hline \multicolumn{1}{c}{ Városrégió } & $\begin{array}{c}\text { Potenciális klaszter } \\
\text { (iparág) }\end{array}$ & Méret (\%) & $\begin{array}{c}\text { Specializáció } \\
\text { (LQ) }\end{array}$ & Fókusz (\%) \\
\hline Szegedi & $\mathrm{CA}$ & 0,35 & 3,98 & 12,52 \\
Kecskeméti & $\mathrm{CA}$ & 0,21 & 3,05 & 9,57 \\
Tatabányai & $\mathrm{CG}$ & 0,17 & 3,71 & 8,40 \\
Nyíregyházai & $\mathrm{CG}$ & 0,15 & 3,53 & 8,00 \\
Székesfehérvári & $\mathrm{CH}$ & 0,38 & 4,48 & 13,95 \\
Miskolci & $\mathrm{CH}$ & 0,23 & 2,86 & 8,93 \\
Szombathelyi & $\mathrm{CI}$ & 0,18 & 3,36 & 10,51 \\
Tatabányai & $\mathrm{CK}$ & 0,27 & 6,77 & 13,47 \\
Győri & $\mathrm{CL}$ & 0,52 & 7,14 & 15,47 \\
Székesfehérvári & $\mathrm{CL}$ & 0,37 & 6,41 & 13,89 \\
\hline
\end{tabular}

Megjegyzések: Méret: adott iparág alkalmazottjainak aránya az adott városrégióban az összes városrégió összes alkalmazottain belül. Specializáció: alkalmazottakra számított lokációs hányados (LQ). Fókusz: az adott iparág alkalmazottjainak aránya adott városrégióban az adott városrégió összes alkalmazottjához viszonyítva.

Ugyancsak néhány városrégióban mutatható ki a fémalapanyag és fémfeldolgozási termék gyártása $(\mathrm{CH})$. Az alág kritikus tömeget ért el a székesfehérvári térségben, valamint a nehézipari múlttal bíró miskolci városrégióban, továbbá kisebb súllyal a salgótarjáni térségben. Ezek közül is a székesfehérvári kiemelkedő, mert a városrégióban alkalmazottak közel 14\%-a ebben az iparágban dolgozik. A potenciális, háromcsillagos klaszterrel rendelkező székesfehérvári és miskolci településegyüttesben néhány nagyvállalat mellett csaknem 150-150 kisvállalkozás van. A 2008-as válság után ez az iparág megerősödött Zalaegerszegen és Salgótarjánban.

A számítógép, elektronikai, optikai termék gyártása (CI) háromcsillagos klaszterként egyedül a szombathelyi térségben jelenik meg a 2010-es adatok alapján, kétcsillagos klaszterként pedig a tatabányai térségben. Számos további olyan városrégió van, ahol kisebb gazdasági súllyal megjelenik ez az alág, pl. a 2008-as válságot követően Zalaegerszegen, Békéscsabán, Szolnokon és Veszprémben. Az alág vállalatai térben elkülönülnek, értékesítésük nagy százaléka külföldön történik. Az alág sajátosságait jól szemlélteti, hogy vállalati mérettől függetlenül viszonylag kevés vállalkozás képviseli az alágat az egyes városrégiókban: csak 16 vállalkozás van az alágban a szombathelyi és 15 vállalkozás a tatabányai térségben. Szombathely esetében ezek a vállalkozások alkalmazzák a városrégió munkaerejének 10,5\%-át.

A gép, gépi berendezések gyártásában (CK) háromcsillagos potenciális klaszter egyedül a tatabányai városrégióban, míg a 2010-es értékek alapján kétcsillagos klaszter egyedül az egri településegyüttesben van. Az összes gép, gépi berendezések gyártásában érintett városrégió közül a tatabányai azért is emelkedik ki, mert a városrégióban alkalmazottak több mint 13\%-a az iparágban dolgozik, és 
a több mint 50 vállalkozás közül négy olyan vállalatnak a székhelye is itt van bejegyezve, amelyek legalább 500 főt alkalmaznak. A 2008-as válság hatására ez az iparág meggyengült Győrben, Székesfehérvárott és Salgótarjánban, míg kissé erőre kapott Veszprémben.

A 2010-es eredmények rámutatnak arra, hogy a jármügyártás (CL) térben koncentrálódik, egyedül a győri és székesfehérvári városrégióban képes kritikus tömeget elérni. Győrben az iparág alkalmazottai a városrégió összes alkalmazottjának több mint 15\%-át teszik ki, az iparág a városrégióban nagymértékben koncentrálódik ( $\mathrm{LQ}=7,14)$. A székesfehérvári térségben a lokációs hányados hasonlóan magas ( $\mathrm{LQ}=6,41$ ), itt a munkaerő közel 14\%-át ebben az iparágban alkalmazzák. A két térségen kívül a 2008-as válságot követően megjelent a kétcsillagos jelző az egri és a szombathelyi városrégióban, míg Veszprémben meggyengült az iparág.

A számítógép, elektronikai, optikai termék gyártása (CI) és a jármügyártás (CL) jelentős súlya betudható az ágazatban lévő külföldi működő tőke nagy arányának is. Napjainkban a külföldi tőke aránya a jegyzett tőkéből ebben a két ágazatban a legmagasabb, meghaladja a 90\%-ot (KSH 2012b). 2012-ben a külföldi tőke állományának csaknem kétharmada ennek a két ágazatnak a 7 vállalkozásában összpontosult (KSH 2012c). Ezek az Audi Hungária Motor Kft. Győrben, a Magyar Suzuki Zrt. Esztergomban, a LuK Savaria Kuplunggyártó Kft. Szombathelyen, a Nokia Komárom Kft., a Samsung Zrt. Budapest agglomerációjában, a Robert Bosch Elektronikai Kft. Miskolcon és az NI Hungary Kft. Debrecenben.

\section{A feldolgozóipari klaszterek térbelisége és a városrégiók típusai}

A vizsgált feldolgozóipari alágak egyedi jellemzői, valamint a háromcsillagos klaszterek jelenléte alapján, figyelembe véve McCann megállapításait a klaszterek sajátosságairól, különböző klasztertípusok és így eltérő sajátossággal rendelkező városrégiótípusok rajzolódnak ki (2. ábra).

Megkülönböztethetünk olyan feldolgozóipari városrégiókat, amelyekben hazai piacra termelő, kritikus tömeget elért potenciális klaszterek vannak (pl. Szeged, Kecskemét). Ezek a klaszterek főleg a beszállítódomináns és fogyasztóorientált iparágakban, mint például az élelmiszeriparban (CA) jönnek létre, amelyekben viszonylag egyszerü technológiákat használnak, kevésbé kvalifikált, de nagy mennyiségű munkaerőt alkalmaznak és a beszállítói kapcsolatok hosszú távúak. Figyelembe véve a McCann-féle tipizálásban felsorolt sajátosságokat és példákat, az élelmiszeriparban lévő klaszterek leginkább régi társadalmi hálózatként jellemezhetők, ahol az együttműködés során fontos szerepe van a vállalatok hasonló történelmi gyökereinek, a hagyományoknak, a kulturális háttérnek, a bizalmi alapú együttműködésnek. Az élelmiszeripari klaszterek ezekben a térségekben fellépő lokalizációs agglomerációs előnyökre építenek. 
2. ábra: Háromcsillagos potenciális feldolgozóipari klaszterek a városrégiókban Three stars potential manufacturing clusters in the city regions

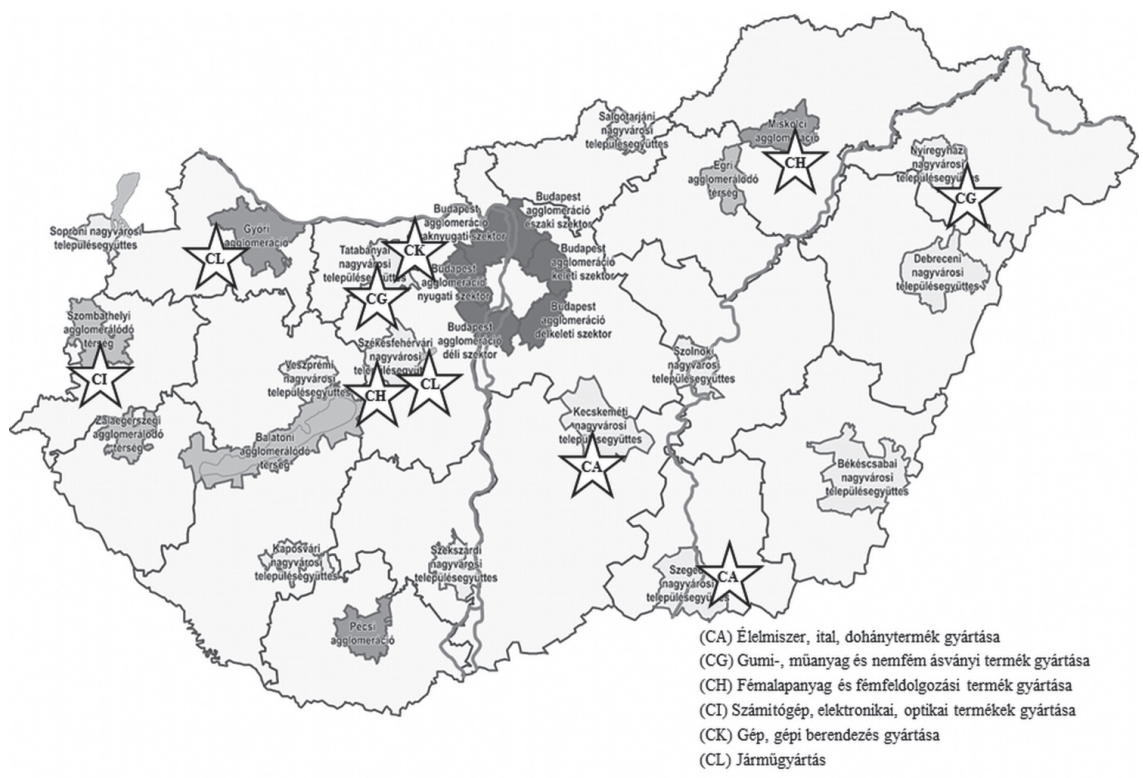

Elkülönülnek azok a várostérségek, ahol a járműgyártáshoz potenciálisan kapcsolódó feldolgozóipari tevékenységek folynak. Ezekben a térségekben olyan termelésintenzív iparágak vannak, mint a gépi berendezések gyártása (CK), amelyek lokalizációs előnyökből profitálnak, szoros kapcsolatban állnak az ügyfeleikkel, és amelyekben a vállalati méret jellemzően kicsi, az innováció forrását gyakran a továbbfelhasználói (pl. járműipari) kapcsolatok jelentik.

A gép, gépi berendezések gyártásáról (CK) láthatóvá vált, hogy azok gyakran a jármügyártásnak (CL) helyet adó, szomszédos városrégiókban koncentrálódnak. Ennek oka lehet a vállalatok tevékenységének jellege, de ugyanúgy a beszállítókkal való együttműködések igénye és az innovációs tevékenységek intenzitása is. A két alág azonban különbözik, hiszen amíg a gépi berendezések gyártásában érintett városrégiók vállalkozásainak nagy része kisvállalkozás, addig a járműgyártásban kiemelkedő két (győri és székesfehérvári) térségben a Cég-Kód-Tár adatai alapján kevés kisméretű, de számos több száz főt alkalmazó cég székhelye található. Tehát a piacot a nagyobb cégek dominálják, amelyek hosszú távú befektetésekben gondolkoznak. A két alág térbelisége és összetétele közötti különbség feltehetően nemcsak a szervezeti méretnek, de a termékek eltérő piaci keresletének és a vállalatok telephelyi hálózatának is betudható.

Ha figyelembe vesszük, hogy Nyugat- és Közép-Dunántúl régiók szomszédos városi térségeiben a járműgyártás meghatározó súllyal bír, a kapcsolódó iparágak is közeli, szomszédos régiókban koncentrálódnak, akkor feltételezhetjük, hogy az ottani gépipari vállalatok tagjává válhatnak az iparági komple- 
xumként leírható (autóipari) klasztereknek. Mindez a járműipari és a kapcsolódó iparágak vállalatainak nagyarányú, jellemzően szerződéses alapú stratégiai együttmüködéséire vezethető vissza, ahol az együttmüködések várhatóan jellemzően hierarchikusak. Hasonló jelenség vázolható fel a gumigyártásról (CG) a tatabányai városrégióban, valamint a fémalapanyag-gyártásról $(\mathrm{CH})$ a székesfehérvári térségben. Ezek az alágak mint kapcsolódó iparágak ugyancsak egy autóipari iparági komplexum részeivé válhatnak.

A fentieken kívül a gumigyártás a nyíregyházai, a fémalapanyag-gyártás a miskolci településegyüttesekben is kritikus tömeget ér el. Az alágak sajátosságait, múltját, a vállalati méreteket tekintve leginkább társadalmi hálózatként jellemezhető klaszterek jöhetnek itt létre, amelyek lokalizációs agglomerációs előnyökre építhetnek.

A tipizálást megtehetjük a tudásteremtő intézmények (felsőoktatás) megléte szerint is. Egyrészt a külföldi működő tőke által irányított járműgyártás (CL) számára köztudottan fontos az egyetemek, föiskolák, valamint az iparágon belüli és az iparágon kívüli (a kapcsolódó iparágakban, pl. gépiparban, gumigyártásban lévő) partnerek földrajzi közelsége. Az iparágat jellemzően néhány multinacionális nagyvállalat dominálja, ennek betudhatóan a korábban is említett iparági komplexumok jöhetnek létre Győr és Székesfehérvár térségében, ahol a helyi, illetve fóvárosi felsőoktatási intézmények egyaránt elérhetők.

Másrészt vannak olyan iparágak, esetünkben a számítógépgyártás (CI), amelyek vállalatai jellemzően a térben szétszórtan helyezkednek el, és amelyek számára a felsőoktatási intézmények közelsége nem szükségszerü. Ebben az iparágban Magyarországon a klaszteresedés lehetőségei alacsonyak, a vállalatok inkább multinacionális cégek részlegeiként, „,szigetként” működnek. E térségekben a helyi multiplikátorhatások várhatóan minimálisak, a térségek jellemzően kívülről vezéreltek és agglomerációs előnyöket alig élveznek. A helyi sajátosságokra építő stratégiák megvalósításába nehéz bevonni ezeket a vállalatokat.

Végül az eredményeink alapján azt is megállapíthatjuk, hogy nincsenek olyan kritikus tömeget elért iparágak, amelyek megfelelnének a szakirodalmi áttekintésben bemutatott ideáltípusoknak. Tiszta agglomeráció az urbanizációs előnyökben részesülő Budapesten, gazdasági tevékenységet tekintve pedig inkább a szolgáltatásokban alakulhat ki.

\section{Összegzés}

A bázisszektorbeli, feldolgozóipari alágak városrégiókban való klaszterfeltérképezésének, az alágak térbeli eloszlásának és kritikus tömegének elemzésekor számos sajátosság mutatkozik, amelyek fontos üzenettel szolgálhatnak a regionális specializációról. Vizsgálatunkból kiderült, hogy a városrégiók eltérő sajátosságokkal rendelkeznek, emiatt különböző feldolgozóipari alágak szerinti 
specializációra van lehetőségük. Az eltérések okai a gazdasági tevékenységek jellegében, a vállalatméretben, de ugyanúgy a technológiai intenzitásban, a külföldi működő tőke arányában, a helyi gazdaságba való beágyazódásban is keresendő. A feldolgozóipari alágak eltérő jellemzői az alágaknak helyet adó térség sajátosságaira is visszahatnak. A feldolgozóipar szempontjából különleges helyzetben van a fóvárosi térség, ahol mindegyik alág megtalálható, de relatíve kis súllyal.

A válság kihatott az alágak várostérségi eloszlására: amíg a járműgyártás (CL) és a gumi- és műanyagipar (CG) térbeli koncentrációja megnőtt, addig az élelmiszeripar (CA) és a számítógép, elektronikai, optikai termékek gyártása (CI) átrendeződött. Az eredmények alapján a hazai vagy a külföldi piacra termelő, kapcsolódó termékeket gyártó, valamint a külföldi működő tőke által vezérelt és a tudásalapú feldolgozóipari alágakban jöhetnek létre klaszterek.

Természetesen a feldolgozóipari vállalkozások kritikus tömege szükséges, de nem elégséges feltételét jelenti a húzóágazatok, klaszterek kialakulásának és sikeres müködésének. Szükséges többek között a felkészült munkaerő, a hálózatosodás, a bizalom, a kiépült üzleti környezet is. Fontos a potenciális húzóágazatok, klaszterek kialakulásához a gazdasági tevékenység bázisjellege és a hazai bázis megléte. Ha láthatóvá válik a városrégiók specializációja, akkor megadható, hogy a nemzetközi gyakorlattal összhangban a tiszta agglomerációra, az iparági komplexumra vagy a társadalmi hálózatra jellemező jegyekkel bíró klaszterek létrejöttére van-e esély.

\section{Köszönetnyilvánítás}

Jelen kutatási eredmények megjelenését az „Ágazati felkészítés a hazai ELI projekttel összefüggo képzési és K+F feladatokra" című, TÁMOP-4.1.1.C-12/1/KONV-2012-0005 azonosítószámú projekt támogatja. A projekt az Európai Unió támogatásával, az Európai Szociális Alap társfinanszírozásával valósul meg.

\section{Jegyzetek}

1 A klaszterek versenyelőnyeit a kapcsolati közelség oldaláról is vizsgálhatjuk (Boschma 2005; Lengyel, Fenyővári, Nagy 2012). A klaszter egyben technológiai, a tanulás és a tudáscsere érdekében létrejött szoros kapcsolatrendszer, amelyhez elengedhetetlen a szereplők kapcsolati közelsége is.

2 A feldolgozóipari alágak változásának hátterében nemcsak a válság, hanem a gazdasági tevékenységek statisztikai besorolásának változása is szerepet játszhat.

3 Az European Cluster Observatory módszertanát némileg módosítjuk, mivel nem európai, hanem magyarországi mintaterületen, a városrégiókban kívánjuk feltárni a potenciális klasztereket. 


\section{Irodalom}

Asheim, B., Smith, H. L., Oughton, C. (2011): Regional innovation systems: Theory, empirics and policy. Regional Studies, 7., 875-891. http://doi.org/bdw3cs

Barta Gy. (2002): A magyar ipar területi folyamatai, 1945-2000. Dialóg Campus Kiadó, Budapest, Pécs

Beaudry, C., Schiffauerova, A. (2009): Who's right, Marshall or Jacobs? The localization versus urbanization debate. Research Policy, 2., 318-337. http://doi.org/ds4bk5

Boschma, R. A. (2005): Proximity and Innovation: A critical assessment. Regional Studies, 1., 61-74. http://doi.org/dbmh2k

Capello, R. (2007): A forecasting territorial model of regional growth: the MASST model. The Annals of Regional Science, 4., 753-787. http://doi.org/c5wxvk

Capello, R. (2008): Space and theoretical approaches to regional growth. In: Capello, R., Camagni, R., Chizzolini, B., Fratesi U. (eds.): Modelling regional scenarios for the enlarged Europe. Springer-Verlag, Berlin, 13-31. http://doi.org/ctnc3h

EC [European Commission] (2009): EU cluster mapping and strengthening clusters in Europe. Brussels

EC [European Commission] (2013): Towards knowledge-driven reindustrialisation. European Competitiveness Report. Brussels

EC [European Commission] (2014): Helping firms grow. European Competitiveness Report. Brussels

Ellison, G., Glaeser, E. (1997): Geographic concentration in U. S. manufacturing industries: A dartboard approach. Journal of Political Economy, 5., 889-927. http://doi.org/fmt2s8

Gecse G., Nikodémus A. (2003): A hazai klaszterek lehatárolásának problémái - lokációs hányados. Területi Statisztika, 6., 507-522.

Iammarino, S., McCann, P. (2006): The structure and evolution of industrial clusters: Transactions, technology and knowledge spillovers, Research Policy, 7., 1018-1036. http://doi.org/cv8vn6

Kiss É. (2010): Területi szerkezetváltás a magyar iparban 1989 után. Dialóg Campus Kiadó, Budapest, Pécs

Kovács T., Tóth G. (2003): Agglomerációs, településegyüttesek a magyar településrendszerben (A területbeosztás 2003. évi felülvizsgálatának eredményei). Területi Statisztika, 4., 387-391.

Krugman, P. (2000): A földrajz szerepe a fejlödésben. Tér és Társadalom, 4., 1-21.

KSH [Központi Statisztikai Hivatal] (2005): Cég-Kód-Tár 2005. 4. negyedév. Budapest

KSH [Központi Statisztikai Hivatal] (2010a): Területi statisztikai évkönyv. Budapest

KSH [Központi Statisztikai Hivatal] (2010b): Cég-Kód-Tár 2010. 4. negyedév. Budapest

KSH [Központi Statisztikai Hivatal] (2012a): Területi statisztikai évkönyv. Budapest

KSH [Központi Statisztikai Hivatal] (2012b): Ipari és épitőipari statisztikai évkönyv. Budapest

KSH [Központi Statisztikai Hivatal] (2012c): A gépipari ágazatok regionális jellemzői. Budapest

Lagendijk, A., Lorentzen, A. (2007): Proximity, knowledge and innovation in peripheral regions. On the intersection between geographical and organizational proximity. European Planning Studies, 4., 457-467. http://doi.org/dfdz8j

Lengyel B., Szanyi M. (2011): Agglomerációs előnyök és regionális növekedés felzárkózó régiókban - a magyar átmenet esete. Közgazdasági Szemle, 10., 858-876.

Lengyel I. (2001): Iparági és regionális klaszterek: tipizálásuk, térbeliségük és fejlesztésük főbb kérdései. Vezetéstudomány, 10., 19-43.

Lengyel I. (2010): Regionális gazdaságfejlesztés. Akadémiai Kiadó, Budapest

Lengyel I., Fenyővári Zs., Nagy B. (2012): A közelség szerepének újraértelmezése az innovatív üzleti kapcsolatokban. Vezetéstudomány, 3., 19-29.

Lengyel I., Rechnitzer J. (2004): Regionális gazdaságtan. Dialóg Campus Kiadó, Budapest, Pécs

Lux G. (2009): Az ipar hagyományos terei: A régi ipari térségek. Tér és Társadalom, 4., 45-60.

McCann, P. (2008) Agglomeration economics. In: Karlsson, C. (ed.) Handbook of research on cluster theory. Edward Elgar, Cheltenham, 23-38. http://doi.org/6bd

McCann, P. (2013): Modern urban and regional economics. Oxford University Press, Oxford

Miller, P., Botham, R., Gibson, H., Martin, R., Moore, B. (2001): Business clusters in the UK. Department of Trade and Industry, London

OECD (1999): Boosting innovation. The cluster approach. Organisation of Economic Co-operation and Development, Paris 
Patik R., Deák Sz. (2005): Regionális klaszterek feltérképezése a gyakorlatban. Tér és Társadalom, 3-4., 139-170.

Porter, M. E. (1998): Clusters and the new economics of competition. Harvard Business Review, 11-12., 77-90.

Porter, M. E. (2000): Locations, clusters, and company strategy. In: Clark, G. L., Gertler, M. S., Feldman, M. P. (eds.): The Oxford handbook of economic geography. Oxford University Press, Oxford, 253-274.

Porter, M. E. (2004): Competitiveness in rural U.S. regions: Learning and research agenda. Institute for Strategy and Competitiveness, Harvard Business School, Boston

Rechnitzer J., Smahó M. (2011): Területi politika. Akadémiai Kiadó, Budapest

Rédei M., Jakobi Á., Jeney L. (2002): Regionális specializáció és a feldolgozóipari tevékenységek változása. Tér és Társadalom, 4., 87-108.

Romer, P. M. (1994): The origins of endogenous growth. The Journal of Economic Perspectives, 1., 3-22. http://doi.org/bbs8mn

Rosenfeld, S. A. (2002): Creating smart systems. A guide to cluster strategies in less favoured regions. European Union and Regional Innovation Strategies. Regional Technology Strategies, Carrboro, North Carolina

Sölvell, Ö. (2009): Clusters and balancing evolutionary and constructive forces. Ivory Tower Publishers, Stockholm

Szakálné Kanó I. (2011): A gazdasági aktivitás térbeli eloszlásának vizsgálati lehetőségei. Statisztikai Szemle, 1., 77-100.

Szilágyi D. (2014): A vidéki agglomerációk társadalmi-gazdasági jellemzői. Területi Statisztika, 6., 606-622.

Tóth G. (2014): Az agglomerációk, településegyüttesek lehatárolásának eredményei. Területi Statisztika, 3., 289-299.

Tödtling, F., Trippl, M. (2005): One size fits all? Towards a differentiated regional innovation policy approach. Research Policy, 8., 1203-1209. http://doi.org/dvs2rd

Trippl, M., Tödtling, F. (2008): Cluster renewal in old industrial regions: Continuity or radical change? In: Karlsson, C. (ed.): Handbook of research on cluster theory. Edward Elgar, Cheltenham, Northampton, 203-218. http://doi.org/6bf

Vas Zs. (2009): Közelség és regionális klaszterek: a szoftveripar Szegeden. Tér és Társadalom, 3., $127-145$.

Wixted, B. (2009): Innovation system frontiers (eletronic resource): cluster networks and global value. Springer-Verlag, Berlin, Heidelberg http://doi.org/bxx796 


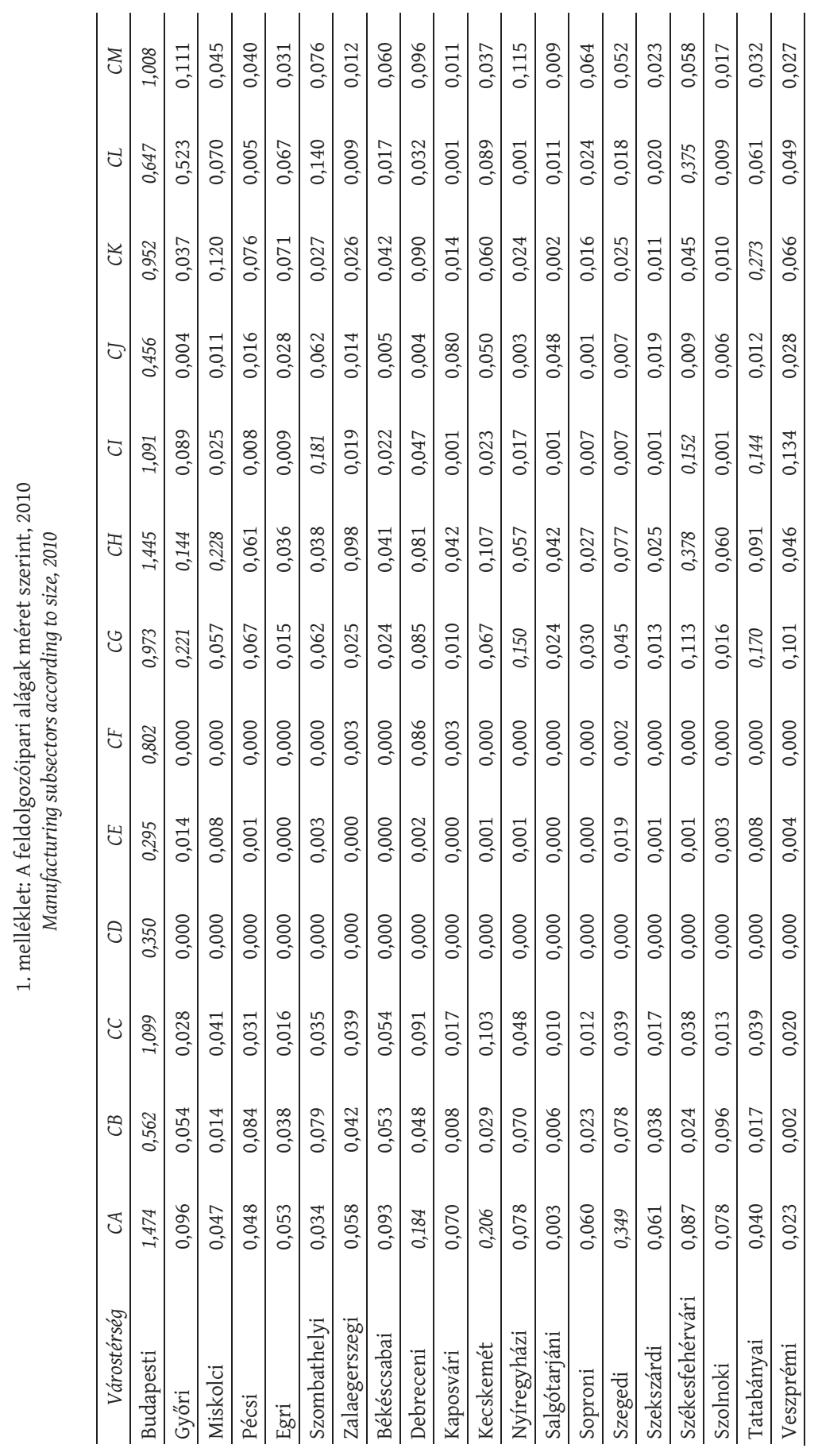




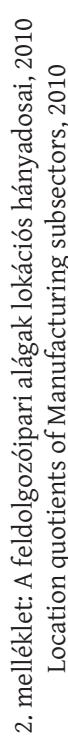

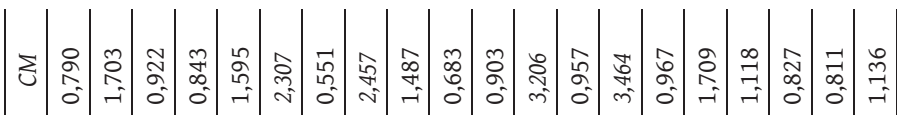

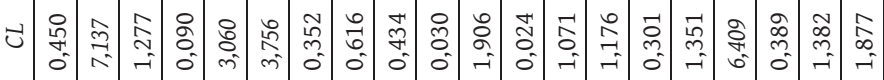

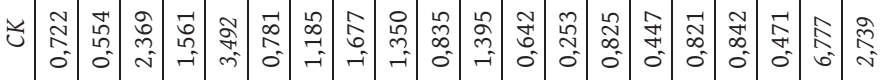

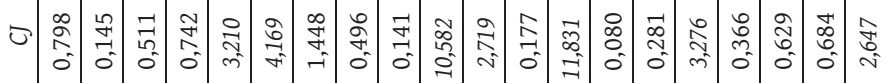

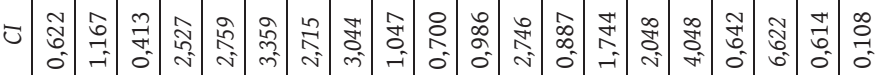

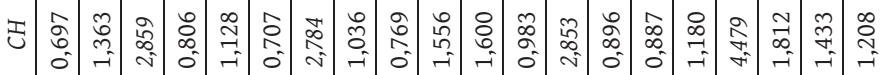

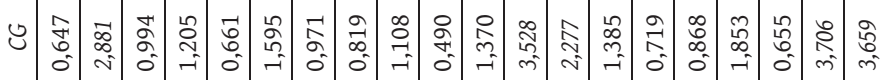

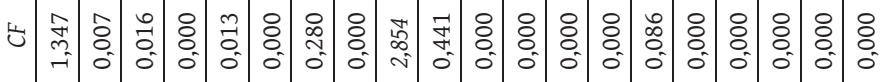

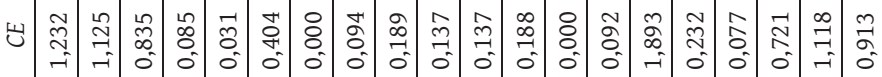

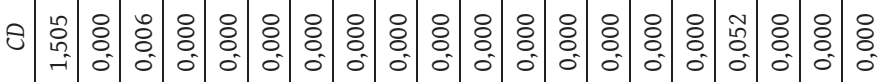

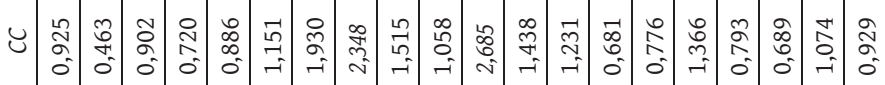

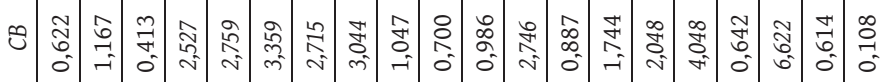

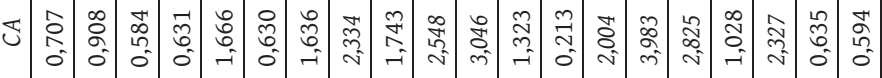

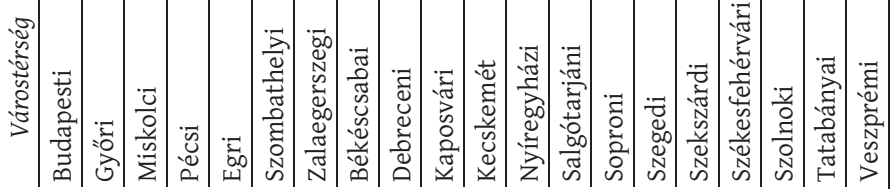




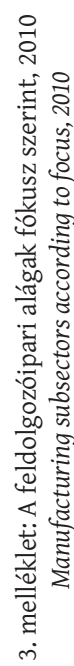

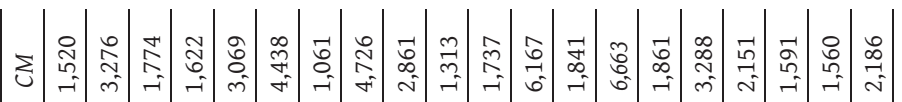

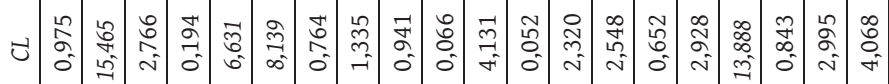

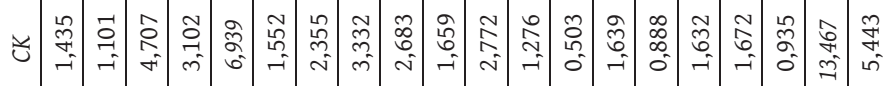

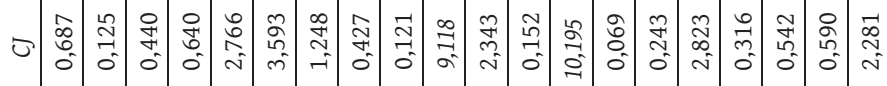

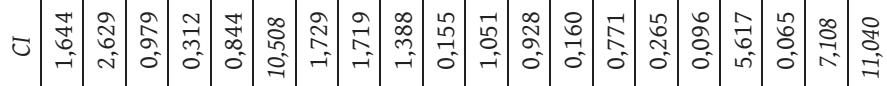

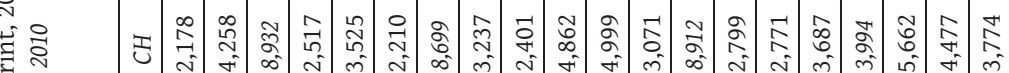

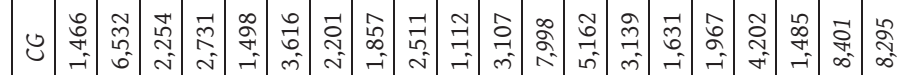

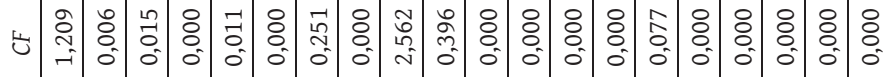

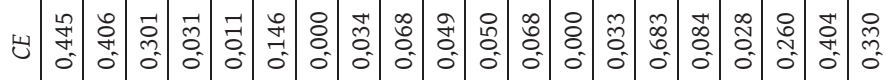

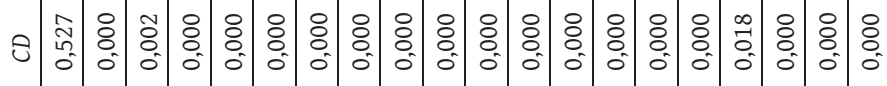

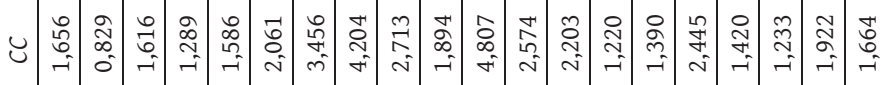

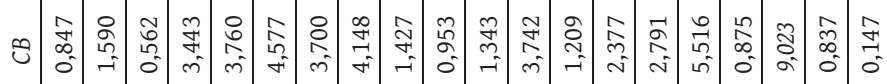

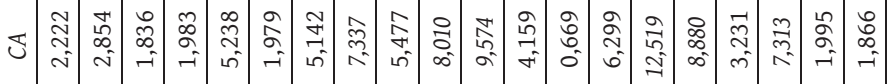

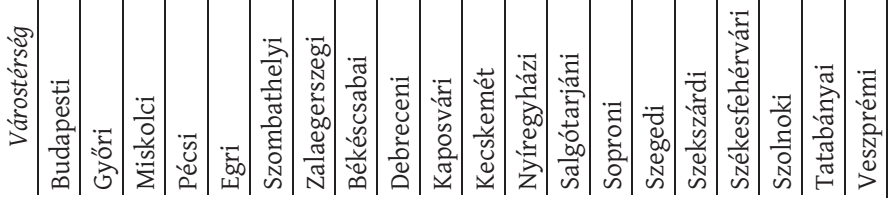

